\title{
A comparative study of functional outcome following internal fixation and conservative management: in non-union clavicle
}

\author{
Saroj Kumar Patra ${ }^{1}$, Bishnu Prasad Patro ${ }^{1}$, Mahesh Chandra Sahu ${ }^{2}$, Sidharth Samal ${ }^{1}$
}

\begin{abstract}
${ }^{1}$ Department of Orthopaedics, IMS and SUM Hospital, Siksha O Anusandhan University, K8, Kalinga Nagar, Bhubaneswar-751003, Odisha, India

${ }^{2}$ Central Research Laboratory, IMS and SUM Hospital, Siksha O Anusandhan University, K8, Kalinga Nagar, Bhubaneswar-751003, Odisha, India
\end{abstract}

Received: 21 December 2015

Revised: 19 January 2016

Accepted: 20 January 2016

\author{
*Correspondence: \\ Dr. Saroj Kumar Patra, \\ E-mail: drsarojk_patra@yahoo.com
}

Copyright: ( $\odot$ the author(s), publisher and licensee Medip Academy. This is an open-access article distributed under the terms of the Creative Commons Attribution Non-Commercial License, which permits unrestricted non-commercial use, distribution, and reproduction in any medium, provided the original work is properly cited.

\section{ABSTRACT}

Background: Clavicle is the only long bone which is horizontally placed and known for its unique characteristics. Clavicle fracture accounts for almost $2 \%$ of total fractures. Most fractures occur in middle third of clavicle and common in young male patients. As of literature $15 \%$ clavicle fracture leads to non -union with decrease functional outcome and decreased Constant and DASH shoulder score. Most orthopedician prefer conservative management unless otherwise definitive indications for surgery like compound fracture or gross displacement with tenting of skin. We tried to find out the functional impairment following non-union of clavicle and its outcome following internal fixation and conservative management.

Methods: In a prospective study 15 patients of non-union clavicle were treated either by internal fixation with bone grafting or by conservative method as per patient will. Six patients were treated with LCDCP with cancellous iliac bone graft and nine patients by conservative management. Constant shoulder score and DASH score of all patients were taken at 2,6 and 12 month. Both the groups were compared in terms of functional outcome and radiological union. Besides we tried to found out the cause of non-union retrospectively with previous mode of management and old radiographs.

Results: We had operated six patients with Plate and screws with cancellous bone graft and rest nine patients by conservative management. At one year follow up operated patients had significant improvement in DASH and Constant shoulder scores with good radiological union compared to the conservative patients.

Conclusions: All young patients with displaced middle $1 / 3^{\text {rd }}$ clavicle fractures should be considered for surgical fixation. Patient with non-union of clavicle with compromised shoulder function can also return to their normal shoulder function following surgery. Plate screw with bone grafting had good results in all six cases. In the conservative group shoulder function was always less in the affected side compared to their normal side.

Keywords: Clavicle, Non-union, Conservative, Locking plate, Screws

\section{INTRODUCTION}

Clavicle fracture accounts for $2 \%$ of all fracture and is common in young males $(68 \%)$ as observed by Neer CS et al. ${ }^{1}$ Clavicle is the first bone to ossify and only long bone placed horizontally. Though famous for his peculiarities, least attention has been given to clavicle fracture. As most of the clavicle fracture unites well with conservative management, it is last attended in a poly trauma patient with multiple fractures. But $15 \%$ of 
clavicle fracture ends with non-union and some degree of shoulder dysfunction remains by conservative management. Treatment of clavicle fracture need more research in terms of ideal management, functional recovery and union.

Clavicle fracture is mostly by direct trauma to shoulder following road traffic accidents, fall from height and sports injury. Fracture is common $(69-81 \%)$ in middle $1 / 3^{\text {rd }}$ of clavicle. Lateral end accounts for $17 \%$ and rest $2 \%$ in medial $1 / 3^{\text {rd }}$ as observed by Van der Meijden OA et al. ${ }^{2-5}$ Clavicular brace, figure of 8 Bandage and Arm sling $^{6,7}$ are preferred modes of conservative treatment worldwide. Surgery is indicated in grossly displaced, comminuted, open fracture, neurovascular involvement, floating shoulder, skin tenting etc. Non-union is seen mostly in displaced or comminuted middle $1 / 3^{\text {rd }}$ fractures. Weight of arm pulls the lateral fragment in caudal direction and sternocleidomastoid muscle pulls the medial fragment in cephalic direction. Because of opposite forces acting on two fragments and soft tissue interposition fracture of middle $1 / 3^{\text {rd }}$ commonly goes to non-union. Different studies have documented $15 \%$ to $21 \%$ risk of non-union following middle $1 / 3^{\text {rd }}$ clavicle fracture. ${ }^{8-10}$ Following non-union there is deficiency of shoulder function as compared to opposite normal shoulder. We have focused on functional outcome following surgery and conservative treatment in patients of non-union clavicle in its middle $1 / 3^{\text {rd }}$. We also tried to find out cause of non-union in a retrospective method from mode of management and previous radiographs.

\section{METHODS}

Total 15 patients with clavicle non-union in middle $1 / 3^{\text {rd }}$ were enrolled in the study in between Jan 2011 to Dec 2013 at IMS and SUM hospital, Bhubaneswar.

Our inclusion criteria includes middle $1 / 3^{\text {rd }}$ non-union clavicle fracture, age range of 18 to 65 yrs. Exclusion criteria are Associated upper limb or shoulder injury, medial and lateral end clavicle non-union.

Out of 16 patients, 1 patient lost to follow up, so rest 15 patients; 12 males and 3 females were included in the study.

Details of injury, fracture pattern, degree of displacement and mode of injury were first listed in all 15 patients. Patients present complaint and DASH and Constant shoulder score was accessed.

Then a prospective trial study started in all patients with observation of radiological union, DASH score and Constant shoulder score. Patient selection was purely on the patient wish either operative or conservative with proper counseling. Expected outcome of each method was explained to each patient. Patients were divided into two groups one group surgical fixation by locking plate and screws with bone grafting and another group conservative with physiotherapy and medication.

All patients were put under the guidance of physiotherapy whether operated or not. Operated patients physiotherapy was started following surgery.

Patients were evaluated by clinical examination, radiograph, DASH (Disability of arm, shoulder and Hand) scores and constant scores at 2 month, 6 month and 1 year follow up. In DASH score the parameters are based on symptoms, physical, social and psychological functions. It's a self-reported scoring system with score results are directly proportional in reverse i.e. maximum score with greater disability. To compensate patient related bias we had also done constant shoulder score at same time interval. It is one of the commonly used scoring system comprises of 4 parts: pain reported by patients (15 points), activities of daily living reported by patients (20 points), range of movements assessed by the examiner (40 points) and strength assessed by the examiner (25points). Maximum score is 100 with better score implies good shoulder function.

At each follow up i.e. 2 months, 6 months and 1year, Xray AP view of clavicle, DASH and constant shoulder scores were recorded by a single qualified person. Based on radiological union, DASH and constant scores, we made a comparative analysis of shoulder functional outcome following surgery and conservative management of non-union middle $1 / 3^{\text {rd }}$ clavicle fracture.

\section{RESULTS}

Before discussing in detail regarding comparative analysis of surgical fixation and conservative management of non-union clavicle we like to highlight some facts about causes of Non-union. Most of the patients had significant fracture displacement (average $1.5 \mathrm{~cm}$ ) and shortening (average $1.2 \mathrm{~cm}$ ) at fracture site. Most of the patients either came for difficulty in doing overhead activities like keeping a heavy luggage in train or bus or cosmetic purpose like prominence at fracture site.

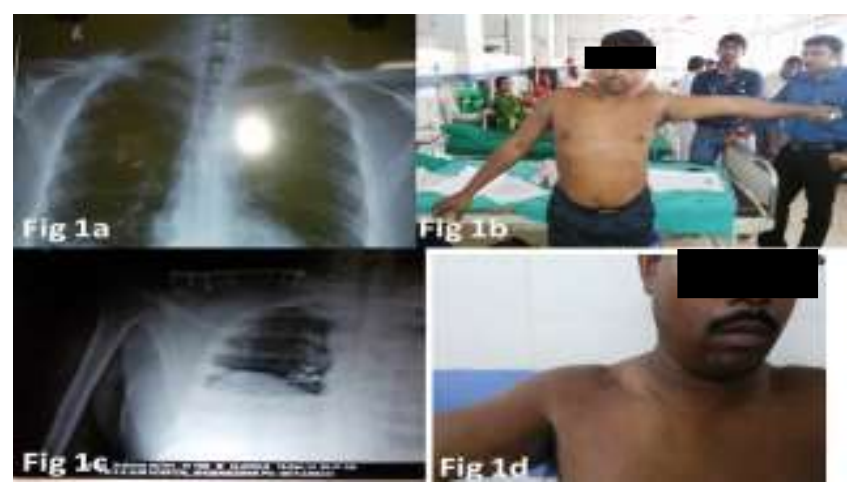

Figure 1: (a) Non-union clavicle; (b) Pre-operative clinical photo; (c) Post-operative X-ray; (d) Postoperative surgical scar. 


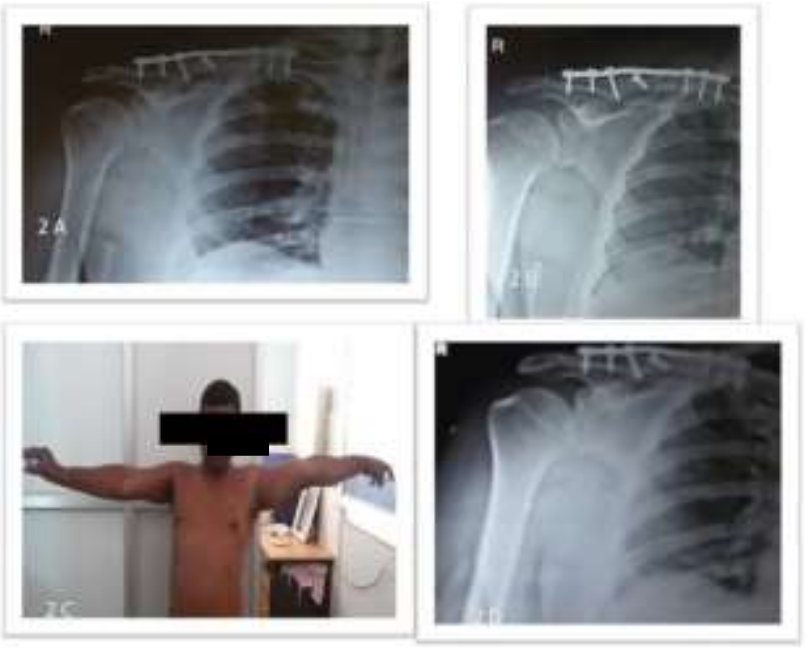

Figure 2: (a) Two months post-operative X-ray; (b) Six months post-operative X-ray; (c) Six months post-operative clinical photo; (d) One year postoperative X-ray.

Both the groups of patients i.e. surgical or conservative groups followed till one year with regular check X-ray, DASH and constant shoulder score.

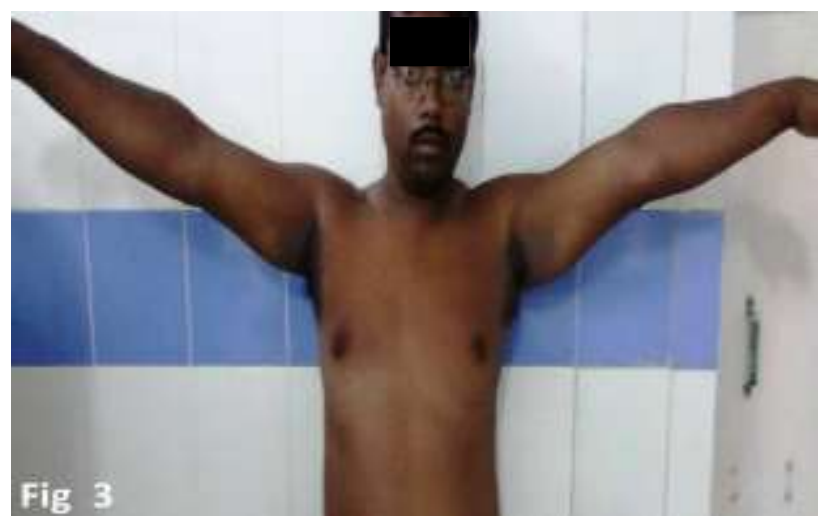

Figure 3: One year post-operative clinical photo.

$5(83 \%)$ out of 6 patients had radiological union by 1 year and only one patient had radiological non-union whereas not a single patient with conservative group had any sign of radiological union. It means without intervention there is rare chance of fracture union in a middle $1 / 3^{\text {rd }}$ clavicle non-union.

Table 1: Observations of conservative group of patients.

\begin{tabular}{|c|c|c|c|c|c|c|c|c|c|c|c|c|}
\hline \multirow[t]{2}{*}{ Sr. No. } & \multicolumn{4}{|c|}{ Radiological union } & \multicolumn{4}{|c|}{ Dash score } & \multicolumn{4}{|c|}{ Constant shoulder score } \\
\hline & $\begin{array}{l}2 \\
\text { months }\end{array}$ & $\begin{array}{l}6 \\
\text { months }\end{array}$ & $\begin{array}{l}1 \\
\text { year }\end{array}$ & $\begin{array}{l}2 \\
\text { years }\end{array}$ & $\begin{array}{l}2 \\
\text { months } \\
\text { Avg- } \\
51\end{array}$ & $\begin{array}{l}6 \\
\text { months } \\
\text { Avg- } \\
45.1\end{array}$ & $\begin{array}{l}1 \text { year } \\
\text { Avg- } \\
444.2\end{array}$ & $\begin{array}{l}2 \text { years } \\
\text { Avg- } 43\end{array}$ & $\begin{array}{l}2 \\
\text { months } \\
\text { Avg- } \\
18\end{array}$ & $\begin{array}{l}6 \\
\text { months } \\
\text { Avg- } \\
22.5\end{array}$ & $\begin{array}{l}\text { 1year } \\
\text { Avg- } \\
26.3\end{array}$ & $\begin{array}{l}2 \\
\text { years } \\
\text { Avg- } \\
27\end{array}$ \\
\hline 1 & No & No & No & No & 47 & 49 & 45 & 42 & 21 & 23 & 24 & 26 \\
\hline 2 & No & No & No & No & 68 & 55 & 58 & 59 & 27 & 30 & 36 & 31 \\
\hline 3 & No & No & No & No & 34 & 28 & 33 & 32 & 15 & 17 & 17 & 19 \\
\hline 4 & No & No & No & No & 57 & 52 & 47 & 51 & 20 & 14 & 21 & 23 \\
\hline 5 & No & No & No & No & 83 & 68 & 79 & 70 & 12 & 15 & 17 & 17 \\
\hline 6 & No & No & No & No & 47 & 44 & 41 & 40 & 14 & 16 & 20 & 21 \\
\hline 7 & No & No & No & No & 28 & 33 & 22 & 25 & 31 & 49 & 58 & 61 \\
\hline 8 & No & No & No & No & 42 & 36 & 38 & 36 & 15 & 19 & 23 & 24 \\
\hline 9 & No & No & No & No & 53 & 41 & 35 & 32 & 17 & 20 & 21 & 21 \\
\hline
\end{tabular}

Table 2: Observations of surgical group of patients.

\begin{tabular}{|c|c|c|c|c|c|c|c|c|c|c|c|c|}
\hline \multirow[t]{2}{*}{ Sr. No. } & \multicolumn{4}{|c|}{ Radiological union } & \multicolumn{3}{|c|}{ Dash score } & \multicolumn{5}{|c|}{ Constant shoulder score } \\
\hline & $\begin{array}{l}2 \\
\text { months }\end{array}$ & $\begin{array}{l}6 \\
\text { months }\end{array}$ & $\begin{array}{l}1 \\
\text { year }\end{array}$ & 2 years & $\begin{array}{l}2 \\
\text { months } \\
\text { Avg- } \\
56\end{array}$ & $\begin{array}{l}6 \\
\text { months } \\
\text { Avg- } \\
40\end{array}$ & $\begin{array}{l}1 \text { year } \\
\text { Avg- } \\
24.6\end{array}$ & $\begin{array}{l}2 \\
\text { years } \\
\text { Avg- } \\
19\end{array}$ & $\begin{array}{l}2 \\
\text { months } \\
\text { Avg- } \\
21\end{array}$ & $\begin{array}{l}6 \\
\text { months } \\
\text { Avg- } \\
33.8\end{array}$ & $\begin{array}{l}1 \\
\text { year } \\
\text { Avg- } \\
44\end{array}$ & $\begin{array}{l}2 \\
\text { years } \\
\text { Avg- } \\
48\end{array}$ \\
\hline 1 & No & No & Yes & Yes & 60 & 46 & 25 & 21 & 17 & 21 & 32 & 35 \\
\hline 2 & No & Yes & Yes & Yes & 95 & 51 & 27 & 9 & 19 & 53 & 67 & 76 \\
\hline 3 & No & No & Yes & Yes & 25 & 18 & 14 & 12 & 15 & 19 & 37 & 41 \\
\hline 4 & No & No & No & Yes & 53 & 48 & 42 & 42 & 21 & 24 & 29 & 32 \\
\hline 5 & No & No & Yes & Yes & 65 & 44 & 21 & 14 & 38 & 43 & 54 & 56 \\
\hline 6 & No & Yes & Yes & Yes & 38 & 33 & 19 & 16 & 16 & 43 & 45 & 48 \\
\hline
\end{tabular}


The average DASH score was 56 (25-95) in surgical group which reduced to 24.6 (14-42) at one year follow up. This depicts there is a significant improvement in surgical group. The average DASH score in conservative group was 51 (28-83) which reduced to 44.2 (22-79) after regular physiotherapy. It means unless otherwise surgical intervention done there is not much improvement in patient satisfaction by physiotherapy.

To avoid patient related bias we evaluated constant shoulder score by independent qualified observer. The Average constant score was 21 (15-38) in surgical group which increase to 44 (29-67) at one year follow up. The average constant shoulder score was 18 (12-31) in conservative group which increased to 26.3 (17-58) at one year follow up.

\section{DISCUSSION}

Retrospective analysis of most non-union clavicle patients revealed displaced or comminuted fracture in old $\mathrm{x}$ ray. So there should be a predictable guidelines based on amount of displacement, shortening or comminution of clavicle fracture, for open reduction and internal fixation. But there is a limitation with this study as retrospectively we studied only non-union cases so there might be some fracture clavicle cases with gross displacement might have recovered well.

Binson et al reported as much as $21 \%$ cases of non-union for displaced clavicle fracture following Non-surgical treatment. ${ }^{9}$ In a Meta-analysis 214 mid shaft clavicle fracture are evaluated and found $15.1 \%$ cases of nonunion in Conservative as compared to $2.2 \%$ in surgical group. ${ }^{8}$ Brinker et al mentioned a 20 to $30 \%$ non-union of displaced clavicle fracture in young males. ${ }^{10}$ Ilija ban et al mentioned that delayed union rate was less in surgical group. ${ }^{11}$

Basically we must know which fracture can lead to nonunion and will need surgical management. Our study is one of the rarest studies to find out the scope of improvement following open reduction and internal fixation and conservative management in established non-union. We had prospectively studied 15 cases of fracture clavicle with non-union. As per their will patients treated either by conservative method or with internal fixation. Non-union and mal-union of clavicle fractures with shortening might have led to winging of scapula, change in glenoid orientation and upward angulation of clavicle at sternoclavicular joint. This result in, decrease in moment arm of individual shoulder girdle muscles, hence the power of muscle. ${ }^{13,14}$ This is thought to be the reason for the residual deficit in shoulder girdle muscle, fatigability as demonstrated by functional and computer modeling studies. ${ }^{12-15}$ Therefore restoration of clavicular length is believed to be pretext for surgical fixation of clavicle especially in young active persons. ${ }^{12,13}$
We observed progressive improvement in both constant shoulder score and DASH score with radiological union in $5(83 \%)$ out of 6 patients treated by open reduction and internal fixation. But patients in conservative group had shown very minimal improvement in both scores. No cases in conservative group had shown any features of radiological union even after one year.

This result is consistent with observation by multi centre randomized clinical trial by Canadian orthopedic trauma society. ${ }^{16}$ All of our surgical groups had shown progressive improvement in both scores which is in consistent with Potter et al. He found that timing of surgical fixation did not result in significant difference in overall function or patient satisfaction. ${ }^{17}$ I presume even after failed conservative treatment, surgical fixation should be considered in young active persons to achieve best shoulder function. The limitations of our study is only limited no of patients were agreed for surgery (six) and treatment option was decided by the patient instead of a randomized manner.

\section{CONCLUSION}

All the patients with grossly displaced or communited mid-shaft clavicle fractures should be considered for surgical fixation. Those young patients with established radiological Non-union should be managed by surgical fixation with bone grafting for improvement of shoulder function.

\section{Funding: No funding sources Conflict of interest: None declared \\ Ethical approval: The study was approved by the institutional ethics committee}

\section{REFERENCES}

1. Neer CS. II Fractures of the distal third of the clavicle. Clin Orthop Relat Res. 1968;58:43-50.

2. Meijden VOA, Gaskill TR, Millett PJ. Treatment of clavicle fractures: current concepts review. J Shoulder Elbow Surg. 2012;21(3):423-9.

3. Stanley D, Trowbridge EA, Norris SH. The mechanism of clavicular fracture. A clinical and biomechanical analysis. J Bone Joint Surg Br. 1988;70(3):461-4.

4. Robinson CM. Fractures of the clavicle in the adult. Epidemiology and classification. J Bone Joint Surg Br.1998;80(3):476-84.

5. Postacchini F, Gumina S, De Santis P, Albo F. Epidemiology of clavicle fractures. J Shoulder Elbow Surg. 2002;11(5):452-6.

6. Andersen K, Jensen PO, Lauritzen J. Treatment of clavicular fractures. Figure-of-eight bandage versus a simple sling. Acta Orthop Scand. 1987;58:71-4.

7. McKee MD. Clavicle fractures in 2010: Sling/swathe or open reduction and internal fixation? Orthop Clin North Am. 2010;41:225-31. 
8. Zlowodzki M, Zelle BA, Cole PA, Jeray K, McKee MD. Evidence-based orthopaedic trauma working group. Treatment of acute mid shaft clavicle fractures: systematic review of 214 fractures: on behalf of the Evidence-based orthopaedic trauma working group. J Orthop Trauma. 2005;19:504-7.

9. Robinson CM, Court-Brown CM, McQueen MM, Wakefield AE. Estimating the risk of non-union following non operative treatment of a clavicular fracture. J Bone Joint Surg Am. 2004;86:1359-65.

10. Brinker MR, Edwards TB, O'Connor DP. Estimating the risk of non-union following non operative treatment of a clavicular fracture. J Bone Joint Surg Am. 2005;87(3):676-7.

11. Ban I, Branner U, Holck K, Krasheninnikoff M, Troelsen A. Clavicle fractures may be conservatively treated with acceptable results-a systematic review. Danish Med J. 2012;59:1-7.

12. Bajuri MY, Maidin S, Rauf A, Baharuddin M, Harjeet S. Functional outcomes of conservatively treated clavicle fractures. Clinics (Sao Paulo). 2011;66:635-9.

13. Ledger M, Leeks N, Ackland T, Wang A. Short malunions of the clavicle: An anatomic and functional study. J Shoulder Elbow Surg. 2005; 14:349-54.
14. Hillen RJ, Burger BJ, Poll RG, de Gast A, Robinson CM. Malunion after mid shaft clavicle fractures in adults. Acta Orthop. 2010;81:273-9.

15. McKee MD, Pedersen EM, Jones C, Stephen DJ, Kreder HJ, Schemitsch EH, et al. Deficits following non-operative treatment of displaced mid shaft clavicular fractures. J Bone Joint Surg Am. 2006;88:35-40.

16. Canadian Orthopaedic Trauma Society. Nonoperative treatment compared with plate fixation of displaced mid shaft clavicular fractures. A multicenter, randomized clinical trial. J Bone Joint Surg Am. 2007;89:1-10.

17. Potter JM, Jones C, Wild LM, Schemitsch EH, McKee MD. Does delay matter? The restoration of objectively measured shoulder strength and patientoriented outcome after immediate fixation versus delayed reconstruction of displaced midshaft fractures of the clavicle. J Shoulder Elbow Surg. 2007; 16:514-18.

Cite this article as: Patra SK, Patro BP, Sahu MC, Samal S. A comparative study of functional outcome following internal fixation and conservative management: in non-union clavicle. Int Surg J 2016;3:291-5. 